\title{
PENDEKATAN DALAM PENANGANAN SENGKETA PILKADA MENUNJANG KINERJA KEPOLISIAN DALAM PELAKSANAAN TUGAS SEBAGAI PELINDUNG, PENGAYOM DAN PELAYAN MASYARAKAT
}

\author{
HUSAIN KASIM \\ Staf Pengajar Jurusan Ilmu Hukum Fakultas Hukum Universitas Nuku Tidore Kepulauan \\ Email : husain.kasim8@yahoo.com
}

\begin{abstract}
This study aims to: 1) knowing the basic law enforcement restorative justice approach in handling criminal acts riots, 2) to know how to implement a restorative justice approach and the factors that influence

The experiment was conducted at the Police Resort Ternate, North Maluku province, with a population of security officers who work directly handling and protection against acts of mass violence with less sampling as many as 50 people through random sampling techniques. Data were collected by questionnaire and interview techniques. Data analysis was performed using qualitative descriptive analysis and interpretation.

The results showed that: 1) The perpetrator of criminal acts of rioting should be avoided from the formal criminal justice system. The best solution that must be done is through the act of diversion (transfer) the completion of its case outside the criminal justice system, but there is no definite legal basis for implementing diversion measures in addition to referring to the Law 2 of 2002, which only specifies that police officers have the authority of police discretion. 2) Treatment of the criminal action in a dispute over the election unrest in North Maluku, which was held on Sat. Criminal Police Ternate is through mediation. This means that the principle of restorative justice has been implemented on Sat. Criminal Police Ternate, however, efforts to address criminal acts there are influences from the substance of the law, law enforcement officers, legal culture of society and their own community.
\end{abstract}

Keywords: approach, handling, restorative, performance,

\section{A. PENDAHULUAN}

Kewenangan yang luas kepada pemerintahan daerah untuk mengatur dan mengurus segala urusan pemerintahan yang didasarkan pada kepentingan masyarakat daerah setempat dan menurut prinsip-prinsip daerah itu sendiri semakin terbuka dengan berlakunya UU No. 32 Tahun 2004, Namun tidak boleh terlepas dari prinsip-prinsip dasar Negara
Kesatuan Republik Indonesia (NKRI). Sebuah langkah maju dalam sistem ketata-negaraan dan sistem pemerintahan di Indonesia terjadi dengan berlakunya UU No. 32 Tahun 2004. Masyarakat dapat menyalurkan aspirasinya secara langsung untuk memilih calon pasangan kepala daerahnya. Berbeda dengan sistem pemilihan kepala daerah sebelumnya, bahwa kepala daerah yang bersangkutan 
tidak dipilih oleh masyakatnya secara langsung, melainkan oleh Dewan Perwakilan Rakyat Daerah (DPRD).

Salah satu peristiwa yang banyak menyita perhatian dan berkenaan dengan kinerja kepolisian adalah sengketa Pilkada yang tidak hanya persoalan antara calon pasangan kepala daerah dan partai-partai politik pendukungnya. Dalam konteks yang lebih luas, sengketa Pilkada juga telah berimbas dalam kehidupan sosial masyarakat. Akibat adanya sengketa Pilkada ini, membuka peluang untuk terjadinya konflik horizontal dalam kehidupan masyarakat. Sering diberitakan bahwa akibat sengketa Pilkada, menyebabkan terjadinya kerusuhan atau bentrok antara massa pendukung calon kepala daerah yang satu dengan massa pendukung calon kepala daerah lainnya. Tidak sedikit kerugian materil yang ditimbulkan, termasuk dapat menyebabkan orang terluka, bahkan sampai ada yang meninggal dunia. Masyarakat yang tidak ikut-ikutanpun dapat menjadi korban kerusuhan tersebut.

Ketidakpuasan terhadap pelaksanaan Pilkada maupun sebab-sebab lainnya merupakan ihwal yang memicu penanganan aksi kerusuhan massa yang menjadi bagian tugas Polri. Terkadang aksi massa sudah tidak dapat dikendalikan lagi, maka aparat kepolisian mengambil tindakan represif dan jika tindakan seperti ini dilakukan, maka tidak jarang institusi Polri ataupun aparat Polri bersangkutan mendapat sorotan dan kritikan tajam dari publik.

Ada satu pendekatan yang menjadi alternative penyelesaian sengketa saat ini. Pendekatan keadilan restoratif dalam penanganan perkara tindak pidana adalah dengan cara melibatkan korban, keluarga dan pihak-pihak lain dalam menyelesaikan masalahnya. Model ini berbeda dengan model pendekatan keadilan retributif, yang hanya melihat terjadinya tindak pidana merupakan hubungan antara pelaku dengan peraturan yang dilanggar, sedangkan yang semestinya pelaku berhubungan dengan korban, keluarga korban, masyarakat ataupun keluarganya. Pendekatan keadilan restoratif mengupayakan mekanisme yang dapat mengumpulkan semua pihak yang bersangkutan untuk sama-sama memikirkan dan menyelesaikan permasalahan yang terjadi dan demi kepentingan masa depan pelaku, keluarganya, korban/keluarga korban ataupun masyarakat.

Aparat kepolisian sebagai salah satu aparat penegak hukum yang langsung berhadapan dengan masyarakat, 
sudah semestinya memahami dan mampu mengimplementasikan pendekatan keadilan restoratif dalam pelaksanaan tugas pokoknya di bidang penegakan hukum. Oleh sebab itu, ketika terjadi aksi kerusuhan massa (tindakan anarkis) yang terkait dengan sengketa dengan pelaksanaan Pilkada, maka untuk penegakan hukumnya, aparat kepolisian diharapkan dapat mengimplementasikan pendekatan keadilan restoratif.

Diakui atau tidak, pelaksanaan Pilkada Propinsi Maluku Utara pada saat itu selalu diwarnai keributan oleh massa pendukung dari pasangan calon kepala daerah. Terjadi antara lain aksi yang menuntut pengunduran tahapan Pilkada, pengusiran massa pendukung yang sedang melaksanakan kampanye karena alasan izin tempat (lokasi) kampanye tidak ada, aksi pemukulan dan perkelahian massal, perusakan baliho, perusakan fasilitas umum, perusakan harta benda milik masyarakat, serta berbagai insiden lainnya yang berimplikasi pidana.

Penerapan model penanganan tindak pidana akibat kerusuhan yang terjadi karena adanya sengketa dalam pelaksanaan Pilkada Propinsi Maluku Utara oleh Polres Ternate ini sekaligus menilai kinerja kepolisian dalam
PENGARUHDISIPLIN KEPOLISIAN TERHADAP KINERJA DALAM PELAKSANAAN TUGAS SEBAGAI PELINDUNG, PENGAYOM DAN PELAYAN MASYARAKAT.

\section{Rumusan Masalah}

1. Bagaimanakah pelaksanaan penanganan tindak pidana aksi kerusuhan terkait sengketa pemilihan Kepala Daerah Propinsi Maluku Utara?

2. Bagaimanakah implementasi pendekatan keadilan restoratif dalam penanganan sengketa pemilihan Kepala Daerah Propinsi Maluku Utara?

3. Bagaimanakah penyelesaian dengan pendekatan tersebut mendukung kinerja kepolisian dalam penanganan sengketa pilkada.

\section{Tujuan Penelitian}

Penelitian ini bertujuan untuk:

1. Mengetahui pelaksanaan penanganan tindak pidana aksi kerusuhan terkait sengketa pemilihan Kepala Daerah Propinsi Maluku Utara?

2. Mengetahui implementasi pendekatan keadilan restoratif dalam penanganan sengketa pemilihan Kepala Daerah Propinsi Maluku Utara? 
3. Mengetahui penyelesaian dengan pandangan Bentham, bahwa tujuan pendekatan tersebut mendukung kinerja kepolisian dalam penanganan sengketa pilkada.

\section{Manfaat Penelitian}

Hasil penelitian ini di harapkan dapat bermanfaat bagi:

1. Institusi POLRI khususnya Polres Ternate dalam melakukan penanganan, pengamanan terhadap maraknya aksi kerusuhan yang dilakukan oleh masyarakat

2. Sebagai referensi dalam pengambilan keputusan yang berkaitan dengan kasus penanganan dan pelayanan terhadap aksi masa kerusuhan.

\section{B. TINJAUAN PUSTAKA}

Ada beberapa teori hukum yang data ditampilkan dalam ranah penegakan hukum dalam sengketa pilkada yang berkait dengan pemaparan kinerja kepolisian dalam penanganan segketa tersebut.

\section{Konsepsi Hukum}

\section{Teori utilistis}

Teori ini dipelopori oleh Jeremy Bentham, menentukan bahwa hukum ingin menjamin kebahagiaan yang terbesar bagi manusia dalam jumlah yang sebanyak-banyaknya (the greatest good of the greatest number). Dengan demikian, menurut teori utilistis dalam

hukum adalah manfaat dalam menghasilkan kesenangan atau kebahagiaan yang terbesar bagi jumlah orang yang terbanyak (Mertokusumo, 2000: 80).

Lebih lanjut dijelaskan Rasjidi dan Thania (2002: 60-61), bahwa: "pemidanaan menurut Bentham, harus bersifat spesifik untuk setiap kejahatan dan berapa kerasnya pidana itu tidak boleh melebihi jumlah dibutuhkan untuk mencegah dilakukannya penyeranganpenyerangan tertentu. Pemidanaan hanya dapat diterima apabila memberikan harapan bagi tercegahnya kejahatan yang lebih besar. Hal yang sama menurut Rasjidi dan Thania (2002: 60-61bahwa pandangan Betham sejalan dengan John Stuart Mill. Menurut John Stuart Mill, sumber dari kesadaran keadilan itu bukan terletak pada kegunaan, melainkan pada ransangan untuk mempertahankan diri dan perasaan simpati. Keadilan bersumber dari naluri manusia untuk menolak dan membalas kerusakan yang diderita, baik oleh diri sendiri maupun oleh siapa saja yang mendapatkan simpati dari kita.

\section{Teori penegakan hukum}

Dalam upaya melaksanakan pembangunan hukum melalui 
pembentukan peraturan perundangundangan, sudah semestinya memperhatikan adanya kecenderungan pertentangan kepentingan serta cita-cita dan sistem nilai yang hidup dalam masyarakat. Menurut Soekanto (2004: 67), masalah pokok penegakkan hukum sebenarnya terletak pada faktor-faktor yang mempengaruhinya. Faktor-faktor tersebut mempunyai arti yang netral, sehingga dampak positif atau negatifnya terletak pada isinya. Adapun faktorfaktor yang mempengaruhi penegakan hukum terdiri dari: faktor hukumnya, faktor aparat penegak hukum, faktor sarana dan prasarana, faktor masyarakat, serta faktor kebudayaan.

\section{Teori kriminologi}

Teori-teori kriminologi lainnya, yaitu Teori Konflik Kebudayaan dari Sellin, yang mengedepankan faktorfaktor perbedaan suku, agama dan sebagainya, menyebabkan orang melakukan tindak pidana. Selanjutnya Teori Kejahatan Ekonomi dari Bonger, menyebutkan bahwa kemiskinan sebagai faktor yang memungkinkan orang bertindak jahat, tetapi dalam praktiknya kejahatan juga dilakukan oleh orang yang tidak miskin. Teori Kriminologi Asosiasi Diferensial dari Sutherland menunjukkan media massa sebagai faktor terjadinya tindak pidana. Teori Kriminologi Anomi dan Kriminologi Subkultur dari Cohen dan Clowed, menunjukkan faktor-faktor perbedaan nilai dan norma antara kelas atas, kelas menengah dan kelas bawah yang mendorong orang melakukan tindak pidana

\section{Kewenangan Kepolisian dalam Penanganan Tindak Pidana Fungsi kepolisian}

Berdasarkan Pasal 2 UU No. 2 Tahun 2002 disebutkan bahwa fungsi kepolisian adalah salah satu fungsi pemerintahan negara di bidang pemeliharaan keamanan dan ketertiban masyarakat, penegakan hukum, perlindungan, pengayoman dan pelayanan pada masyarakat. Penjelasan Pasal 2 menegaskan bahwa dalam menjalankan fungsinya anggota kepolisian harus memperhatikan semangat penegakan hak asasi manusia (HAM), hukum dan keadilan.

Dalam hal terjadinya tindak pidana, maka berdasarkan Pasal 16, anggota Polri berwenang untuk:

a. melakukan penangkapan, penahanan, penggeledahan, dan penyitaan;

b. melarang setiap orang meninggalkan atau memasuki tempat kejadian perkara untuk kepentingan penyidikan; 
c. membawa dan menghadapkan orang kepada penyidik dalam rangka penyidikan;

d. menyuruh berhenti orang yang dicurigai dan menanyakan serta memeriksa tanda pengenal diri;

e. melakukan pemeriksaan dan penyitaan surat;

f. memanggil orang untuk didengar dan diperiksa sebagai tersangka atau saksi;

g. mendatangkan seorang ahli yang diperlukan dalam hubungannya dengan pemeriksaan perkara;

h. mengadakan penghentian penyidikan;

i. menyerahkan berkas perkara kepada penuntut umum;

j. mengajukan permintaan secara langsung kepada pejabat imigrasi yang berwenang di tempat pemeriksaan imigrasi dalam keadaan mendesak atau mendadak untuk mencegah atau menangkal orang yang disangka melakukan tindak pidana;

k. memberi petunjuk dan bantuan penyidikan kepada penyidik pegawai negeri sipil serta menerima hasil penyidikan penyidik pegawai negeri sipil untuk diserahkan kepada penuntut umum; dan l. mengadakan tindakan lain menurut hukum yang bertanggungjawab.

Ketentuan tentang penyelidikan dan penyidikan diatur juga dalam Undang-undang Nomor 8 Tahun 1981 tentang Hukum Acara Pidana (KUHAP). Dalam Pasal 1 angka 5 disebutkan bahwa penyelidikan adalah serangkaian tindakan penyelidikan untuk mencari dan menemukan suatu peristiwa yang diduga sebagai tindak pidana guna menentukan dapat atau tidaknya dilakukan penyidikan menurut cara yang diatur dalam undangundang ini. Selanjutnya dalam Pasal 1 angka 2, disebutkan pula bahwa penyidikan adalah serangkaian tindakan penyidik dalam hal dan menurut cara yang diatur dalam undang-undang ini untuk mencari serta mengum-pulkan bukti yang dengan bukti itu membuat terang tentang tindak pidana yang terjadi dan guna menemukan tersangkanya.

\section{Diversi dan diskresi kepolisian}

Di Indonesia aparat kepolisian mempunyai kewenangan diskresi, seperti yang diatur dalam Pasal 18 UU No. 2 Tahun 2002, yang menentukan bahwa untuk kepentingan umum, pejabat Polri dalam melaksanakan tugas dan wewenangnya dapat bertindak menurut penilaiannya sendiri. Salah satu kewenangan diskresi ini adalah melalui 
tindakan diversi dan tentunya tindakan diversi yang dilakukan tidak boleh melanggar aturan hukum yang berlaku.

Berdasarkan ketentuan ini, maka kepada aparat kepolisian diberikan kewenangan khusus (diskresi) untuk melakukan pengalihan (diversi) yang menghindarkan pelaku tindak pidana dari proses sistem peradilan pidana formal, penahanan ataupun pemenjaraan. Program diversi ini dapat dilakukan dengan berbagai macam cara, antara lain adalah melalui mediasi dan konsiliasi.

\section{Keadilan restoratif}

Keadilan adalah suatu yang sukar didefinisikan, tetapi dapat dirasa-kan dan merupakan unsur yang tidak dapat dipisahkan dari hukum sebagai perangkat asas dan kaidah yang menjamin keteraturan dan ketertiban dalam masyarakat (Kusumaatmadja dan Sidharta, 2000: 52). Sebenarnya ukuran nilai keadilan dapat dilihat dari dua aspek. Selain aspek idealnya, nilai keadilan mempunyai aspek empiris, artinya bahwa ukuran nilai keadilan dalam konteks hukum (aspek ideal) harus dapat diaktualiasasikan secara konkrit menurut manfaatnya (aspek empiris). Dengan adanya ukuran manfaat nilai keadilan, maka keadilan dapat dipandang menurut konteks empiris (Manulang, 2007: 100).

Dalam sistem hukum pidana Indonesia, telah berkembang suatu konsep keadilan yang tidak hanya melihat keadilan itu hanya dari satu sisi, melainkan menilainya dari kepentingan berbagai pihak, baik kepentingan si korban, masyarakat maupun kepentingan si pelaku. Keadilan yang dimaksudkan di sini bukanlah keadilan yang berarti menjatuhkan hukuman yang sesuai tindakan si pelaku, melainkan suatu keadilan yang dikenal dengan keadilan restoratif.

Tony Marshall sebagaimana dikutip Hidayat (2005: 26) menyebutkan bahwa: "keadilan restoratif adalah proses yang melibatkan semua pihak pada kejahatan, khususnya untuk memecahkan secara bersama-sama bagaimana mengatasi akibat dari suatu kejahatan dan implikasinya di masa mendatang”.

\section{METODE PENELITIAN}

\section{Pendekatan penelitian}

Penelitian ini terutama untuk melihat gejala-gejala sosial tentang penanganan tindak pidana dengan pendekatan keadilan restorasi akibat adanya aksi kerusuhan dalam sengketa Pilkada dan data yang diperoleh 
nantinya akan dipaparkan secara lisan dalam uraian kalimat, maka pendekatan paling tepat digunakan dalam penelitian adalah pendekatan kualitatif.

\section{Jenis penelitian}

jenis penelitian yang digunakan adalah metode studi kasus, karena dengan menggunakan metode ini dapat diperoleh gambaran secara mendalam terhadap satu kasus tertentu tentang pendekatan keadilan restoratif dalam penanganan tindak pidana. Hal ini sesuai dengan pendapat Azwar (2004: 8), bahwa: "metode studi kasus merupakan metode penelitian yang mencoba melakukan penelitian yang mendalam mengenai suatu kasus sosial sedemikian rupa sehingga menghasilkan gambaran yang utuh dan terorganisir dari kasus tersebut.”

\section{Lokasi Penelitian}

Sesuai judul penelitian yang ditetapkan, maka lokasi penelitian ini dilaksanakan pada institusi Polres Ternate, tetapi berhubung penelitian ini juga membutuhkan data sekunder dalam bentuk data dokumen, maka lokasi penelitiannya juga dilaksanakan pada Perpustakaan Pascasarjana Universitas Hasanuddin.

\section{Sumber Data}

Sumber data yang utama dalam penelitian kualitatif adalah kata-kata dan tindakan dari orang-orang yang diamati atau diwawancarai, selebihnya hanya merupakan data tambahan, misalnya dokumen dan lain-lain (Moleong, 2001: 112). Sumber data lapangan dalam penelitian ini diperoleh dari Polres Ternate.

\section{Teknik Pengumpulan Data}

Metode studi dokumen diperlukan untuk mendapatkan data sekunder, yang terdiri dari bahan hukum primer, bahan hukum sekunder dan bahan hukum tertier. Teknik wawancara yang digunakan dalam penelitian ini adalah dengan menggunakan pedoman wawancara terstruktur yang telah direncanakan dan disusun sesuai dengan kebutuhan penelitian.

\section{Teknik Analisis Data}

Penyusunan laporan penelitian dalam bentuk tesis dilaksanakan dengan menggunakan teknik analisis yuridis kualitatif.

\section{HASIL PENELITIAN DAN PEMBAHASAN}

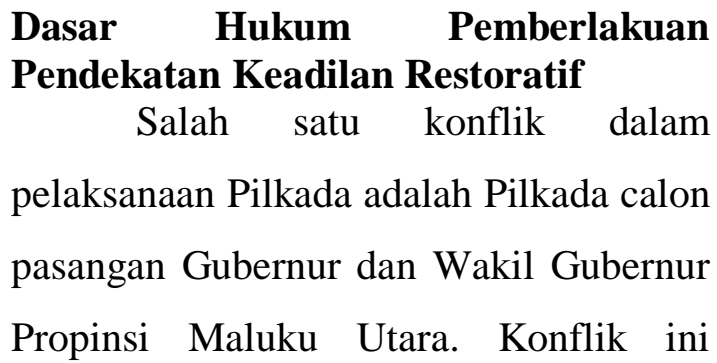


sempat menjadi sorotan publik dan menambah daftar sengketa yang terjadi pada pelaksanaan Pilkada. Menurut Kapolres Ternate (wawancara tanggal 16 November 2010), dikatakan bahwa: “sengketa Pilkada Maluku Utara, diawali adanya isu pasangan Mudafar Syah dan Rusdi Hanafi tidak lolos dalam tahap verifikasi yang dilaksanakan oleh KPUD Maluku Utara.”

Penjelasan lebih lanjut oleh Kapolres Ternate (wawancara tanggal 16 November 2010), dikatakan bahwa:

“KUPD memang tidak meloloskan pasangan Mudafar Syah dan Rusdi Hanafi sebagai pasangan Calon Gubernur/Wakil Gubernur Maluku Utara. Hal ini telah menyebabkan terjadinya berbagai aksi kerusuhan yang dilakukan oleh massa pendukung Mudafar Sjah yang juga merupakan Sultan Ternate dalam bentuk:

1. pemblokiran jalan untuk menuju Kecamatan Kota Ternate Utara dengan menggunakan batu;

2. pemblokiran bandara Babullah Ternate;

3. perusakan taman kota berupa penebangan pohon hias dan pot bunga yang ada di sepanjang jalan Kecamatan Kota Ternate Utara; dan
4. terjadinya bentrok fisik antara masyarakat pendukung Mudafar Sjah yang didominasi masyarakat kesultanan dengan aparat kepolisian, sehingga menimbulkan jatuhnya korban di kedua belah pihak, karena pihak kepolisian melakukan pembubaran paksa terhadap massa yang telah bertindak anarkis.”

Implikasi pidana dalam sengketa Pilkada Maluku Utara sebenarnya cukup kompleks, tidak hanya diakibatkan oleh ketidaklolosan pasangan Mudafar Syah dan Rusdi Hanafi dalam verifikasi yang dilaksanakan KPUD Maluku Utara, tetapi juga karena berbagai sebab lainnya. Kapolres Ternate (wawancara tanggal 16 November 2010), mengatakan bahwa: “implikasi pidana dalam sengketa Pilkada juga karena adanya aksi massa pendukung salah satu calon yang menuntut pengunduran jadwal Pilkada, penetapan jadwal kampanye, aksi yang menuntut Ketua KPUD Provinsi Maluku Utara (M. Rahmi Husen) agar mundur dari jabatannya karena tidak netral, bahkan isu kegiatan kampanye yang harus dibatalkan karena tidak mendapat ijin penggunaan lapangan Sunyie Lamo Kelurahan Salero Kecamatan Kota Ternate Utara secara resmi dari Sultan 
Ternate yang merupakan hak milik Kesultanan.”

Pendekatan keadilan restoratif perlu dilakukan, karena keberadaan hukum dalam masyarakat, sebenarnya tidak hanya dapat diartikan sebagai sarana untuk menertibkan kehidupan masyarakat, melainkan juga sebagai sarana yang mampu mengubah pola pikir dan perilaku warga masyarakatnya. Selain itu, hukum juga harus berfungsi untuk melindungi kepentingan setiap anggota masyarakat, tanpa melihat status, jenis kelamin, suku, jabatan dan semua hal lain terkait dengan predikatnya. Sehubungan dengan hal ini, maka setiap manusia yang ada di muka bumi (baik anak-anak, orang dewasa ataupun janin masih dalam kandungan seorang wanita), harus mendapatkan perlindungan oleh hukum. Oleh sebab itu, tanpa melihat predikat seseorang dalam dalam masyarakat, maka pelaku tindak pidana sekalipun, harus mendapatkan perlindungan oleh hukum. Bentuk perlindungan hukum yang diberikan kepada mereka ini (pelaku tindak pidana), misalnya harus diperlakukan secara manusiawi dengan menghormati martabat pribadinya sebagai manusia.

Menurut Kapolres Ternate (wawancara tanggal 16 November 2010) dan Ka. Sat. Reskrim Polres Ternate (wawancara tanggal 17 November 2010), bahwa:

“pendekatan keadilan restoratif dalam penanganan tindak pidana aksi kerusuhan dapat dilihat/dekati dari sudut pandang (aspek sosiologis). Berdasarkan aspek sosiologis, pemberlakuan keadilan restoratif ini didasarkan pada pertimbangan, bahwa umumnya pelaku tindak pidana kerusuhan, bukan didorong oleh kemauan yang memang muncul secara sadar dari dalam dirinya (faktor genetika), melainkan karena faktor atau pengaruh yang berasal dari luar dirinya, yaitu karena adanya kesalahan sistem demokrasi dalam pelaksanaan Pilkada Maluku Utara.”

Dilihat dari sudut (aspek) yuridis, penanganan tindak pidana aksi kerusuhan dengan mengedepankan prinsip keadilan restoratif, belum ada landasan yuridis tegas yang dapat dijadikan standar acuan (pedoman). Namun demikian, menurut Kapolres Ternate (wawancara tanggal 16 November 2010) dan Ka. Sat. Resrim Polres Ternate (wawancara tanggal 16 November 2010) dikatakan bahwa: "jika ditelaah secara kritis, sebenarnya ada dua pasal yang dapat dijadikan dasar pedoman bagi aparat kepolisian untuk melaksana-kan pendekatan keadilan 
restoratif dalam penanganan tindak pidana aksi kerusuhan, yaitu:

1. Pasal 16 ayat (1) huruf l. Berdasar ketentuan ini maka dalam rangka menjalankan tugas aparat kepolisian dapat mengadakan tindakan lain menurut hukum yang bertanggungjawab. Tindakan lain yang dimaksudkan disini dapat ditafsirkan secara lebih luas, termasuk dalam melaksanakan tindakan diversi (pengalihan) penanganan perkara tindak pidana.

2. Pasal 18, yang menegaskan bahwa untuk kepentingan umum, pejabat Polri dalam melaksanakan tugas dan wewenangnya dapat bertindak menurut penilaian sendiri. Bertindak menurut penilaian sendiri merupakan kewenangan yang dikenal dengan istilah diskresi kepolisian.

Pendekatan keadilan restoratif merupakan proses keadilan yang sepenuhnya dijalankan dan dicapai oleh masyarakat. Proses yang benar-benar harus sensitif terhadap kebutuhan masyarakat dan benar-benar ditujukan untuk mencegah dilakukannya kembali tindak pidana. Hal ini menjadikan keadilan sebagai sesuatu yang penuh dengan pertimbangan dalam merespon kejahatan dan menghindari terjadinya stigmatisasi.

Demikian pula halnya dalam penanganan kasus tindak pidana aksi kerusuhan dengan mempergunakan konsep keadilan restoratif, adalah penanganan yang melibatkan semua komponen lapisan masyarakat dan aparat penegak hukum, secara bersama-sama bermusyawarah untuk menentukan tindakan terbaik bagi pelaku tindak pidana. Penyelesaian dengan cara ini bertujuan untuk memulihkan kembali kerugian yang telah ditimbulkan oleh pelaku tindak pidana aksi kerusuhan. Oleh karena itu, pelaku tindak pidana aksi kerusuhan dituntut pertanggungjawaban dalam bentuk pemberian ganti rugi materil kepada korban atau melaksanakan kerja sosial atau mengikuti pendidikan/pelatihan yang berguna baginya.

Selanjutnya Kapolres Ternate (wawancara tanggal 16 November 2010), menjelaskan bahwa tindakan diversi dapat menjadi bentuk keadilan restoratif jika:

1. Mendorong pelaku untuk bertanggungjawab atas perbuatannya.

2. Memberikan kesempatan kepada pelaku untuk mengganti kesalahan 
yang dilakukan dengan berbuat demikian, bukan berarti kebutuhan kebaikan bagi si korban.

3. Memberikan kesempatan bagi korban untuk ikut serta dalam proses penyelesaian.

4. Memberikan kesempatan bagi pelaku untuk dapat mempertahankan hubungan dengan keluarga.

5. Memberikan kesempatan terciptanya rekonsiliasi dan perbaikan bagi masyarakat yang dirugikan.

Menurut penjelasan Penyidik pada Sat. Reskrim Polres Ternate (wawancara tanggal 19 November 2010) dikatakan bahwa: implementasi tindakan diversi yang dilaksanakan didasarkan pada kelima konsep di atas, berhubung sampai saat ini belum ada Jutlak ataupun Juknis yang dapat dijadikan paramater untuk melaksanakan pendekatan prinsip keadilan restoratif dalam penanganan tindak pidana aksi kerusuhan.”

Pendekatan Keadilan Restoratif dan Dukungan Terhadap Peningkatan Kinerja Kepolisian.

\section{Metode pendekatan keadilan restoratif}

Kebutuhan dan keselamatan korban menjadi perhatian yang utama dari proses keadilan restoratif. Korban harus didukung dan dapat dilibatkan secara langsung dalam proses penentuan kebutuhan dan hasil akhir dari kasus tindak pidana yang dialaminya. Namun pelaku tindak pidana diabaikan. Pelaku tindak pidana harus direhabilitasi dan direintegrasikan dalam masyarakat. Menurut Ka. Sat. Reskrim Polres Ternate (wawancara tanggal 17 November 2010), dikatakan bahwa:

"proses keadilan restoratif merupakan proses keadilan yang sepenuhnya dijalankan dan dicapai oleh masyarakat. Proses yang benar-benar harus sensitif terhadap kebutuhan masyarakat dan benar-benar ditujukan untuk mencegah dilakukannya kembali tindak pidana. Hal ini menjadikan keadilan sebagai sesuatu yang penuh dengan pertimbangan dalam merespon kejahatan dan menghindari terjadinya stigmatisasi. Sehingga sangat disadari perlu dijalankannya suatu mekanisme monitoring di dalam masyarakat terhadap pelaksanaan hasil akhir dari penyelesaian suatu tindak pidana, menyediakan dukungan dan dibukanya kesempatan yang luas bagi stakeholders kunci.

Pendekatan keadilan restoratif dalam penanganan tindak pidana terkait sengketa Pilkada Maluku Utara juga bertujuan untuk menghindarkan pelakunya dari proses pemidanaan yang terkadang dirasakan belum dapat mencerminkan nilai-nilai keadilan 
Faktor aparat penegak hukum juga dapatmempengaruhi pengimplementasian pendekatan keadilan restoratif dalam penanganan tindak pidana. Aparat penegak hukum yang dimaksud disini adalah para anggota Sat. Reskrim Polres Ternate yang melaksanakan penanganan tindak pidana aksi kerusuhan. Faktor pengaruh dari aparat penegak hukumnya dapat dilihat dari 2 (dua) sisi, yaitu dari sisi kuantitas dan kualitas. Kalau dilihat dari kedua sisi ini, sebenarnya kendala utama adalah dari sisi kualitas, karena menurut Ka. Satreskrim Polres Ternate (wawancara tanggal 17 November 2010), bahwa: “aparat penyidik Sat. Reskrim Polres Ternate umumnya belum mempunyai keahlian memadai untuk melaksanakan penanganan tindak pidana aksi kerusuhan dengan pendekatan keadilan restoratif.” Selain itu, menurut penjelasan Kapolres Ternate (wawancara tanggal 16 November 2010), bahwa:

"Pimpinan (Atasan) dapat mempengaruhi pengimplementasian pendekatan keadilan restoratif dalam penanganan tindak pidana, karena walaupun Anggotanya paham tentang metode pendekatan keadilan restoratif dalam penanganan tindak pidana, mereka tidak akan berani melaksanakannya kalau tidak ada petunjuk atau perintah dari Pimpinan
(Atasan). Oleh sebab itu, Pimpinan (Atasan) juga harus memahami pentingnya pendekatan keadilan restoratif dalam penanganan tindak pidana, berhubung keberhasilan dari pelaksanaan penanganan tindak pidana dengan pendekatan keadilan restoratif ini dipengaruhi oleh dukungan dari Pimpinan.

Secara obyektif, norma hukum yang hendak ditegakkan mencakup pengertian hukum formal dan hukum materiil. Hukum formal hanya bersangkutan dengan peraturan perundang-undangan yang tertulis, sedangkan hukum materiil mencakup pula pengertian nilai-nilai keadilan yang hidup dalam masyarakat, walaupun dalam bahasa tersendiri, orang sangat sulit membedakan antara pengertian penegakan hukum dengan penegakan keadilan.

\section{Prosedur penanganan tindak pidana aksi kerusuhan dengan pendekatan keadilan restoratif mencerminkan kinerja kepolisian}

Menurut Kapolres Ternate (wawancara tanggal 16 November 2010), bahwa:

“upaya yang dilakukan dalam rangka penanganan kasus kerusuhan dilaksanakan dengan: 
a. sosialisasi melalui tokoh agama dan masyarakat, organisasi kemasyarakatan dan masyarakat luas secara langsung atau tatap muka;

b. dialog interaktif baik langsung maupun melalui radio dan televisi lokal;

c. publikasi dalam berbagai event dan media guna menghimbau masyarakat agar tidak terpancing oleh issu yang menyesatkan;

d. Membuat pola koordinasi penanganan tindak pidana kerusuhan dan mengimplementasikannya;

e. Melakukan rapat-rapat koordinasi antar stakehorlders dalam rangka mencegah akibat yang mungkin lebih luas;

f. Melaksanakan kerjasama dan memperkuat sinergitas, serta penyamaan persepsi dalam upaya penyelesaian akibat dari kerusuhan; dan

g. Melaksanakan dan mengikuti berbagai pertemuan dengan instansi terkait untuk meningkatkan perluasan jaringan kerja.”

Untuk mengatasi akibat tindak pidana kerusuhan terkait dengan sengketa Pilkada Maluku Utara, maka yang perlu dilakukan adalah menyangkut dengan masalah penegakan hukumnya. Sebagai salah satu aparat penegak hukum, maka tugas dan fungsi Polri dalam kasus tindak pidana tersebut adalah melakukan penyelidikan dan penyidikan, yang selanjutnya menyusun berita acara pemeriksaan perkara untuk diteruskan kepada kejaksaan guna penyusunan berkas penuntutan. Aparat Polri yang bertugas melaksanakan penyidikan tindak pidana ini perlu dibekali pengetahuan khusus, karena dampak tindak pidana kerusuhan ini cukup kompleks.

Terkait dengan pelaksanaan penyidikan tindak pidana tersebut, maka menurut Penyidik pada Sat. Reskrim Polres Ternate (wawancara tanggal 19 November 2010), bahwa: “pemeriksaan terhadap tersangka, korban dan saksisaksi dilaksanakan dengan cara tanya jawab langsung di Polres Ternate”. Ka. Sat. Reskrim Polres Ternate (wawancara tanggal 17 November 2010), mengatakan bahwa: “dalam penanganan perkara tindak pidana kerusuhan ini, berpedoman pada peraturan yang berlaku, tetapi pendekatan keadilan restoratif tetap lebih didahulukan”. Terkait dengan masalah penanganan terhadap tindak pidana kerusuhan tersebut, Ka. Sat. Reskrim Polres Ternate, menjelaskan lebih lanjut bahwa: "secara khusus tetap mengacu pada ketentuan yang terdapat dalam 
KUHP, KUHAP, UU No. 2 Tahun 2002, serta undang-undang lain yang relevan”.

Selain itu, dalam hal telah terjadinya tindak pidana kerusuhan ini, maka harus pula diupayakan pemberian perlindungan terhadap korban dan pelakunya. Sebagaimana penjelasan Ka. Sat. Reskrim Polres Ternate (wawancara tanggal 17 November 2010), bahwa:

"Perlindungan bagi korban tindak pidana antara lain adalah dengan mencarikan bantuan advokasi hukum, sedangkan perlindungan terhadap pelaku tindak pidana ini adalah dengan mengupayakan penyelesaian perkara di luar dari sistem peradilan pidana yang formal (tindakan diversi). Alasan untuk mengalihkan perkaranya (tindakan diversi) ditujukan guna menghindarkan pelaku dari sistem peradilan pidana yang biasanya selalu memberikan dampak buruk terhadap dirinya. Bentuk pelaksanaan tindakan diversi dilakukan berdasarkan kebijakan aparat kepolisian dengan mempertimbang-kan prinsip keadilan restoratif. Adapun tindakan diversi yang dilaksanakan adalah dalam bentuk pertanggungjawaban atas per-buatan yang dilakukan pelaku, antara lain dengan pemberian ganti rugi materil kepada korban.”
Lebih lanjut Ka. Sat. Reskrim Polres Ternate juga menjelaskan bahwa:

"Pelaksanaan pemberian ganti kerugian, baik dalam menentukan jenis, besar maupun pelaksanaan pembayaran ganti kerugian, dilakukan melalui proses mediasi antara pelaku dengan korban. Namun demikian, proses mediasi bukan semata-mata terkait dengan masalah ganti rugi. Manfaat lebih luas dalam proses mediasi bertujuan agar pelaku dan korban dapat berdiskusi tentang tindak pidana yang telah terjadi dan akibat tindak pidana tersebut, baik terhadap diri korban, pelaku maupun masyarakat pada umumnya, serta bertujuan untuk memulihkan keadaan menjadi lebih baik. Dalam pelaksanaan mediasi antara korban dengan pelaku, pihak kepolisian sendiri hanya berperan sebagai fasilitator demi kelancaran penyelenggaraan proses mediasi itu sendiri.”

Ka. Sat. Reskrim Polres Ternate (wawancara tanggal 17 November 2010) menjelaskan bahwa: “penanganan tindak pidana kerusuhan terkait sengketa Pilkada Maluku Utara memang tidak menunjuk seorang mediator, namun demikian Penyidik Sat. Reskrim Polres Ternate dengan dibantu oleh tokoh masyarakat dan advokat di Ternate, 
bertindak seperti halnya seorang mediator.

Penilaian Kinerja Kepolisian dalam penanganan tindak pidana dengan pendekatan keadilan restoratif

Pendekatan keadilan restoratif dalam penanganan perkara tindak pidana aksi kerusuhan harus dapat memberikan manfaat atau keuntungan bagi banyak pihak terkait, terutama bagi pelaku, korban dan bagi masyarakat. Oleh sebab itu, penanganan tindak pidana aksi kerusuhan perlu mengedepankan bentuk keadilan restoratif ini. Perlunya pendekatan seperti ini sesuai Teori Utilistis bahwa tujuan hukum adalah memberikan kebahagiaan sebesarbesarnya kepada orang sebanyakbanyaknya.

Polisi sebagai aparat pengayom, pelindung, dan pelayan masyarakat dapat dicapai dengan pola kerja yang sigap dengan penerapan peraturan serta pemanfaatn pola yang baru berupa pendekatan restorative. Berdasarkan Teori Utilistis tersebut, maka dalam penanganan perkara tindak pidana aksi kerusuhan, solusi yang terbaik adalah dengan pendekatan keadilan restoratif dan sesuai dengan pendapat Kapolres Ternate (wawancara tanggal 16 November 2010) dan Ka. Sat. Reskrim Polres Ternate (wawancara tanggal 16
November 2010), yang mengata-kan bahwa:

“dengan pendekatan keadilan restoratif, banyak pihak yang akan memperoleh manfaatnya, adapun manfaat langsung yang dapat diperoleh pelaku tindak pidana adalah terkait dengan pemenuhan dan perlindungan atas hak-haknya dan mendidiknya untuk menjadi orang yang bertanggungjawab atas kerusakan yang telah dibuat-nya. Selanjutnya terhadap korban, dapat memperoleh ganti kerugian untuk memperbaiki semua kerusakan atau kerugian yang dideritanya akibat perbuatan yang dilakukan oleh pelaku.

Arman Mandar yang merupakan salah satu pelaku tindak pidana kerusuhan (wawancara tanggal 23 November 2010), mengatakan bahwa: "manfaat yang didapatkan dari proses penanganan tindak pidana kerusuhan dengan pendekatan keadilan restoratif antara lain bahwa saya tetap dapat melanjutkan aktifitas sehari-hari dan tetap dapat bertemu dengan keluarga, berbeda misalnya kalau saya dipidana, maka hal ini tidak mungkin dapat saya rasakan.”

Pendapat lain yang disampaikan oleh Hendra K., salah seorang korban tindak pidana (wawancara tanggal 23 November 2010), dikatakan bahwa: 
"melalui pendekatan keadilan restoratif dalam penanganan tindak pidana kerusuhan tersebut, saya merasa telah terjadi perubahan paradigma aparat kepolisian dalam penanganan tindak pidana, karena saya tidak hanya dianggap sebagai objek, melainkan ikut terlibat secara aktif dalam menyelesaikan akibat tindak pidana itu sendiri, dan yang lebih penting bahwa kerugian yang saya derita dapat diganti (direhabilitasi) oleh pelakunya secara sadar dan tanpa paksaan”.

Berdasarkan penjelasan di atas, maka perlu diciptakan pergeseran konsep keadilan dalam penyelesaian perkara pidana, yaitu dari keadilan atas dasar pembalasan (retributive justice) yang melekat pada sistem peradilan pidana, ke arah keadilan yang bersifat restoratif (restorative justice), yang menekankan pentingnya aspek restoratif atau penyembuhan bagi mereka yang menderita karena kejahatan. Akhirnya polisi sebagai pengayom, pelindung dan pelayan masyarakat juga dapat mencapai fungsinya kaena penyelesaian secara winwin solution lebih membawa rasa damai di masyarakat dan berkeadilan. Sehingga dengan demikian citra polisi pun menjadi lebih segar terbuka dan terterima sebagai pejabat Negara dengan peran yang diembannya.

\section{E. PENUTUP}

\section{Kesimpulan}

Berdasarkan uraian pada bab sebelumnya dan sesuai dengan pokok permasalahan yang dikaji, maka dapat ditarik kesimpulan sebagai berikut:

1. Pelaku tindak pidana aksi kerusuhan harus dihindarkan dari sistem peradilan pidana formil. Solusi terbaik yang harus dilakukan adalah melalui tindakan diversi (pengalihan) penyelesaian perkaranya di luar sistem peradilan pidana, tetapi belum ada dasar hukum yang pasti untuk melaksanakan tindakan diversi selain mengacu pada UU No. 2 Tahun 2002, yang hanya menentukan bahwa aparat Polri memiliki kewenangan diskresi kepolisian.

2. Penanganan terhadap pelaku tindak pidana aksi kerusuhan dalam sengketa Pilkada Maluku Utara, yang dilaksanakan pada Sat. Reskrim Polres Ternate adalah melalui mediasi. Hal ini berarti bahwa prinsip keadilan restoratif sudah diimplementasikan pada Sat. Reskrim Polres Ternate.

3. Penanganan secara restoratif memndukung posisi penguatan 
kinerja kepolisian dalam fungsinya sebagai pengayom, pelindung, dan pelayan masyarakat.

\section{Saran-saran}

1. Perlu adanya peraturan perundangundangan (kebijakan) yang dapat dijadikan pedoman untuk melaksanakan penanganan tindak pidana yang dapat diselesaikan dengan cara pendekatan keadilan restoratif melalui tindakan diversi, tidak hanya dalam tataran kebijakan yang dikeluarkan oleh Polri, tetapi dalam bentuk undang-undang.

2. Mengingat bahwa dalam upaya penanganan tindak pidana aksi kerusuhan dengan pendekatan keadilan restoratif masih menemui hambatan dari masyarakat, maka sosialisasi dalam bentuk penyuluhan kepada masyarakat tentang arti penting pendekatan keadilan restoratif perlu terus ditingkatkan.

\section{DAFTAR PUSTAKA}

Adi, Rianto. 2005. Metode Penelitian Sosial dan Hukum, Edisi Kedua, Granit, Jakarta.

Azwar, Saifuddin. 2004. Metode Penelitian, Pustaka Pelajar, Yogyakarta.

Fuady, Munir. 2003. ArbitrasNasional, Alternatif Penyelesaian Sengketa
Bisnis, Citra Aditya Bakti, Bandung.

Hadikusuma, Hilman. 1992. Pengantar Ilmu Hukum Adat Indonesia Mandar Maju, Bandung.

Harahap, M. Yahya. 1995. "Mencari Sistem Alternatif Penyelesaian Sengketa”, Varia Peradilan, No. 21, Jakarta

Hidayat, Taufik. 2005. "Restorative Justice Sebuah Alternatif”, dalam Jurnal Restorasi, Edisi IV, Volume 1.

Islakomputer. http://islakomputer.com, diakses tanggal 22 November 2010.

Kelana, Momo. 2002. Memahami Undang-undang Kepolisian (Undang-undang Nomor 2 Tahun 2002), Latar Belakang dan Komentar Pasal Demi Pasal, PTIK Press, Jakarta.

Koentjaraningrat. 1993. Metode-metode Penelitian Masyarakat, Edisi Ketiga, Gramedia, Jakarta.

Kusumaatmadja, Mochtar dan Sidharta, B. Arief. 2000. Pengantar Ilmu Hukum, Suatu Pengenalan Pertama Ruang Lingkup Berlakunya Hukum, Buku I, Alumni, Bandung.

Manulang, E. Fernando. 2007. Menggapai Hukum Berkeadilan, Tinjauan Hukum Kodrat dan Antinomi Nilai, Kompas Media Nusantara, Jakarta.

Melani. "Membangun Sistem Hukum Pidana dari Retrebutif ke 
Restoratif”, Jurnal Litigasi, Vol. 6 No. 3 Oktober 2005.

Mertokusumo, Sudikno. 2000. Mengenal Hukum, Suatu Pengantar, Edisi Kelima, Cetakan Pertama, Liberty, Yogyakarta.

Moleong, Lexy J. 2001. Metodologi Penelitian Kualitatif, Remaja Rosdakarya, Bandung.

Mudzakir. 2005. "Viktimologi Studi Kasus di Indonesia”, Makalah, disampaikan pada Penataran Hukum Pidana dan Kriminologi Ke-XI, Surabaya.

Muhammad, Farouk dan Djaali, H. 2005. Metodologi Penelitian Sosial, Edisi Revisi, PTIK Press dan Restu Agung, Jakarta.

Nuryani, Rena Yulia. 2009. "Restorative Justice Sebagai Alternatif Perlindungan Hukum Terhadap Korban Kekerasan dalam Rumah
Tangga”, Tesis, Program Pascasarjana Universitas Islam Bandung, Bandung.

Purwoko, Bambang. 2005. "Isu-isu Strategis Pilkada Langsung: Ekspresi Kedaulatan untuk Mewujudkan Kesejahteraan Rakyat”, Swara Politika, Volume 6 Nomor 1.

Rasyidi, Lili dan Putra, I.B. Wyasa. 2003. Hukum Sebagai Suatu Sistem, Mandar Maju, Bandung.

Rasyidi, Lili dan Rasyidi, Ira Thania. 2002. Pengantar Filsafat Hukum, Mandar Maju, Bandung.

Republik Indonesia, Undang-undang Nomor 2 Tahun 2002 tentang Kepolisian Negara Republik Indonesia.

Republik Indonesia, Undang-undang Nomor 8 Tahun 1981 tentang Hukum Acara Pidana. 
